\title{
Spatial and temporal analysis of the LST-NDVI relationship for the study of land cover changes and their contribution to urban planning in Monte Hermoso, Argentina
}

\author{
Federico Ferrelli \\ María Andrea Huamantinco Cisneros \\ Ana Laura Delgado \\ María Cintia Piccolo \\ Universidad Nacional del Sur (UNS)-CONICET. Instituto Argentino de Oceanografía (IADO) \\ Universidad Nacional del Sur (UNS). Departamento de Geografía y Turismo \\ fferrelli@criba.edu.ar \\ mandreahc@criba.edu.ar \\ aldelgado@iado-conicet.gob.ar \\ ofpiccol@criba.edu.ar
}

\begin{abstract}
The aim of this work was to study the spatial distribution of Land Surface Temperature (LST) and its relationship with diverse urban land covers and the Normalized Difference Vegetation Index (NDVI). The study area was Monte Hermoso city, which is located in the southwest of Buenos Aires province, Argentina. To obtain the LST and NDVI parameters, satellite images from LANDSAT 5 TM and LANDSAT 7 ETM+ sensors were seasonally processed for the period 2008-2012. Visual interpretation techniques and empirical intervention were applied to design an urban land cover map on which LST and NDVI were analyzed by tracing four transects oriented in latitudinal and longitudinal directions. Each urban cover presented a particular behavior of these parameters. Furthermore, significant results for the relationship between LST and NDVI were observed (with $\alpha 0.1$ and 0.05 ) with $\mathrm{R}^{2}$, Pearson, and Spearman indices values higher than 0.7. Finally, LST variation in diverse land covers was observed as a consequence of urban growth and the alteration of the vegetation coverage. Therefore, it was concluded that the spatial and temporal variation of LST values may indicate modifications in urban land covers. The information obtained in this study would be a useful tool to guide future urban management studies and policies.
\end{abstract}

Keywords: Land Surface Temperature (LST); Normalized Difference Vegetation Index (NDVI); seasonal distribution; satellite imagery processing; Monte Hermoso 
Resum. Anàlisi espacial i temporal de la relació TST-NDVI per a l'estudi dels canvis de cobertura del sòl $i$ la seva contribució per a la planificació urbana (Monte Hermoso, Argentina)

L'objectiu d'aquesta investigació va ser estudiar la distribució espacial de la temperatura de superfície terrestre (TST), la seva relació amb diferents cobertures del sòl urbà i l'índex de vegetació de diferència (NDVI). L’àrea d'estudi seleccionada va ser la ciutat costanera de Monte Hermoso, localitzada al sud-oest de la província de Buenos Aires (Argentina). Per fer-ho, es van processar imatges satel-litàries LANDSAT 5 TM i 7 ETM + per al període 2008-2012 de manera estacional. Amb aquestes imatges es va calcular la TST i l'NDVI. Posteriorment, es van aplicar tècniques d'interpretació visual i es van fer sortides al camp per dissenyar un mapa de cobertures del sòl urbà. Sobre aquestes, es va analitzar la variació de la TST i l'NDVI mitjançant el traçat de quatre transsectes orientats en sentit latitudinal i longitudinal. Cadascuna d'aquestes cobertures va presentar un comportament particular dels paràmetres calculats. D'altra banda, es van observar resultats significatius de la relació TST-NDVI (amb $\alpha$ de 0,1 i 0,05), amb valors de $\mathrm{R}^{2}$, índexs de Pearson i Spearman més grans de 0,7 . Finalment, es va evidenciar que el canvi en les cobertures del sòl, producte del creixement urbà, va modificar els valors estacionals de la TST. Aquests van ser generats com a conseqüència de l'alteració de la coberta vegetal. Per tant, es va concloure que les variacions espaciotemporals de la TST podrien indicar canvis en l'ús del sòl propis de l'expansió urbana. Per l'anàlisi realitzada, es considera que la informació obtinguda en aquest estudi serà útil per orientar polítiques d'ordenament del territori.

Paraules clau: temperatura de superfície terrestre (TST); índex de vegetació de diferència normalitzada (NDVI); distribució estacional; processament d'imatges de satèl.lit; Monte Hermoso

Resumen. Análisis espacial y temporal de la relación TST-NDVI para el estudio de los
cambios de cobertura del suelo y su contribución para la planificación urbana (Monte Hermoso,
Argentina)

El objetivo de esta investigación fue estudiar la distribución espacial de la temperatura de superficie terrestre (TST), su relación con distintas coberturas del suelo urbano y el índice normalizado de vegetación (NDVI). El área de estudio seleccionada fue la ciudad costera de Monte Hermoso, localizada en el sudoeste de la provincia de Buenos Aires (Argentina). Para llevarlo a cabo, se procesaron imágenes satelitales LANDSAT 5 TM y 7 ETM + para el período 2008-2012 de forma estacional. Con ellas, se calculó la TST y el NDVI. Posteriormente, se realizó un reconocimiento del terreno y se aplicaron técnicas de interpretación visual para diseñar un mapa de coberturas del suelo urbano. Sobre estas, se analizó la variación de la TST y el NDVI a través del trazado de cuatro transectos orientados en sentido latitudinal y longitudinal. Cada una de las coberturas identificadas presentaron un comportamiento particular de los parámetros calculados. Por otro lado, se observaron resultados significativos de la relación TST-NDVI (con $\alpha$ de 0,1 y 0,05 ), con valores de $\mathrm{R}^{2}$, índices de Pearson y Spearman mayores que 0,7. Las modificaciones en los valores estacionales de la TST evidenciaron un cambio en las coberturas del suelo, producto del crecimiento urbano. Los mismos fueron generados como consecuencia de la alteración de la cobertura vegetal. Por lo tanto, se concluyó que las variaciones espacio-temporales de la TST podrían indicar cambios en el uso del suelo propios de la expansión urbana. Por el análisis realizado, se considera que la información obtenida en este estudio será útil para orientar políticas de ordenamiento del territorio.

Palabras clave: temperatura de superficie terrestre (TST); índice normalizado de vegetación (NDVI); distribución estacional; procesamiento de imágenes satelitales; Monte Hermoso 
Résumé. Analyse spatiale et temporelle de la relation TST-NDVI pour l'étude des changements de la couverture terrestre et sa contribution à la planification urbaine (Monte Hermoso, Argentine)

Le but de ce travail était d'étudier la répartition spatiale de la Température de la Surface Terrestre (TST) et sa relation avec différentes couvertures de terrains urbains et l'indice de végétation normalisé (NDVI). La zone étudiée était la ville de Monte Hermoso, située au sud-ouest de la province de Buenos Aires (Argentine). Tout d'abord, des images satellite LANDSAT 5 TM et LANDSAT 7 ETM + capteurs ont été traitées de façon saisonnière sur la période de 2008 à 2012. Ensuite, ces données ont été utilisées pour le calcul des paramètres TST et NDVI. Par la suite, des techniques d'interprétation visuelle et d'intervention empirique ont été appliquées afin de concevoir une carte de couverture du sol urbain sur laquelle la LST et le NDVI ont été analysés en traçant quatre transects orientés dans des directions latitudinale et longitudinale. Chaque couverture urbaine a présenté une réponse particulière de ces paramètres. En outre, des résultats significatifs pour la relation entre LST et NDVI ont été observés (avec $\alpha 0,1$ et 0,05 ) avec des valeurs de $\mathrm{R}^{2}$, indices de Pearson et Spearman supérieures à 0,7. Enfin, une modification de la TST de la couverture terrestre, due à la croissance urbaine, a été observée. Ces changements ont été générés à la suite d'une modification de la couverture végétale. Par conséquent, il a été conclu que la variation spatiale et temporelle des valeurs de LST pourrait indiquer des changements dans la couverture du sol urbain. Lors de cette étude, il a été considéré que l'information obtenue était utile pour orienter les politiques de gestion urbaine.

Mots-clés: Température de la surface terrestre (TST); Indice de différence de végétation normalisée (NDVI); la répartition saisonnière; traitement d'images satellitaires; Monte Hermoso

\author{
Summary \\ 1. Introduction 5. Discussion \\ 2. Study area 6. Conclusions \\ 3. Data and methods Acknowledgments \\ 4. Results Bibliographical references
}

\title{
1. Introduction
}

The development of artificial spaces and the replacement of natural surfaces and forms in cities are known to work as major drivers of change in the local climate. Coastal cities are considered to be climatically comfortable and healthy environments for residents and tourists. In these places, the climate is a key resource for the development and consolidation of most tourism activities (García, 2009).

Remote sensing techniques are a valuable tool for studying urban climates as they permit the development of high resolution temporal and spatial results. Infrared thermal images allow the distinction of three urban units: asphalt concrete surfaces, edifications, and urban open spaces. Because asphalt con- 
crete surfaces store heat during the day and slowly emit it at night, the radiation level is still considerably high at dawn. Moreover, based on the specific characteristics of the vegetation captured by satellite imagery, the detection of temperate, fresh or cold spaces has become possible (Deosthali, 2000; Kim and Baik, 2004). For Valencia, Spain, Valor et al. (2000) reported that the city is occasionally cooler than the nearby environment in the first hours of the day due to urban building shadows, while the proximities are already being heated by the sun.

Numerous studies have used diverse satellite products to determine and characterize the urban climate and urban heat islands (e.g., Pérez et al., 2003; Rosenzweig et al., 2005; Wong and Yu, 2005; Chen et al., 2006; Yuan and Bauer, 2007; Santana, 2007; Ferrelli et al., 2015). However, few studies have been carried out on the application of remote sensing to urban climate research in Argentina. Ripoll et al. (2010) determined the thermal conditions of green areas in San Juan, Argentina, using satellite imagery. Other studies have dealt with the variation of land uses (Chiementon and Cogliati, 2011) and the inference of air temperature with the Normalized Difference Vegetation Index (NDVI) (Cúnsulo et al., 2012).

It has become imperative to study urban land uses and the associated variations in Land Surface Temperature (LST), since population growth exerts excessive pressure on the environment, thus modifying and degrading it (Kaufmann et al., 2007). Building over green areas produces changes in the heat exchange, water, trace gases, aerosols and momentum balance between the land surface and overlying atmosphere (Crutzen, 2004). As a consequence, these changes are associated to alterations in the thermal gradient, which could affect the comfort of urban residents (Deosthali, 1999). Furthermore, the study of urban spaces has become key in understanding global environmental change (Grimmond, 2007), since these spaces are the main source of carbon dioxide, which is released to the atmosphere for the nature of activities that take place there, thus affecting the carbon balance and the climate heating (Pataki et al., 2003; Velasco and Roth, 2010).

Given the changes occurring in cities and the fact that they will continue to expand, the study of urban land cover changes and their impacts on thermal patterns and NDVI values has a pivotal interest. In particular, the city of Monte Hermoso, Argentina, has experienced continuous growth in recent years due to the increase in tourism. Like other cities, urban growth in Monte Hermoso was uncontrolled, which has affected the land cover and thus thermal behavior. Therefore, we believe that it is necessary to investigate urban changes to guide future responsible urban planning policies. This study aims to answer the following basic questions: How can thermal urban changes be detected? and How can the urban land cover be determined to guide urban planning policies? Considering the lack of coastal urban studies in Argentina, the main objective of this work was to analyze LST related to land uses and variations of NDVI in the coastal city of Monte Hermoso using satellite imagery (LANDSAT 5 TM and 7 ETM+) for the period 2008-2012. The secondary objective 
was to propose remote sensing as a useful tool to obtain environmental data in urban climate studies as an alternative to in situ data acquisition. Finally, the study of LST variability in urban spaces is a key factor in tourism and urban planning and natural resource management.

\section{Study area}

Monte Hermoso is a coastal city located in the southwest of the Buenos Aires Province, Argentina (Figure 1). During the study period (2008-2012) the mean air temperature was $15.2^{\circ} \mathrm{C}$, with a mean temperature of $21.4^{\circ} \mathrm{C}$ in summer and $8.5^{\circ} \mathrm{C}$ in winter. In the intermediate seasons (autumn and spring), the mean temperatures were $16.7^{\circ} \mathrm{C}$ and $14.2^{\circ} \mathrm{C}$, respectively. These results are in line with previous studies on the marked seasonal differences in temperature in this area (Huamantinco Cisneros, 2012).

Following the foundation of Monte Hermoso in 1979, the city's population grew steadily. According to the national institute of statistics, 3100 people lived permanently in the city in 1980 and by 2010 the population had doubled (INDEC, 2011). Tourism is the principal economic activity in the city, with summer being the high season.

The urban area is rectangular in shape and runs parallel to the coastline, with an extension of 186 ha. Since the city is located on coastal dunes, the terrain is irregular. Furthermore, due to the lack of urban planning, most of the dunes have been replaced with buildings and streets without considering the environmental impact.

Figure 1. Location of the study area



Source: Own elaboration.

\section{Data and methods}

LST and urban land covers were analyzed using seasonal LANDSAT 5 TM and LANDSAT 7 ETM+ images (Path-Row 226-087), which were selected 
Table 1. Dates and sensor of the selected images. $\left(^{*}\right)$ L5-TM and $\left(^{* *}\right)$ L-7 ETM+

\begin{tabular}{|c|c|c|c|c|}
\hline Year & Summer & Autumn & Winter & Spring \\
\hline 2008 & $1^{\text {st }}$ February $\left(^{* \star}\right)$ & $21^{\text {st }}$ April $\left.{ }^{(\star *}\right)$ & $8^{\text {th }}$ June $\left(^{* *}\right)$ & $6^{\text {th }}$ October $\left(^{*}\right)$ \\
\hline 2009 & $10^{\text {th }}$ January $\left(^{*}\right)$ & $8^{\text {th }}$ April $\left(^{* \star}\right)$ & $11^{\text {th }}$ June $\left(^{(\star *}\right)$ & $26^{\text {th }}$ November (*) \\
\hline 2010 & $6^{\text {th }}$ February $\left(^{* \star}\right)$ & $27^{\text {th }}$ April $\left.{ }^{(* *}\right)$ & $30^{\text {th }}$ June $\left(^{* \star}\right)$ & $12^{\text {th }}$ October $\left(^{*}\right)$ \\
\hline 2011 & $1^{\text {st }}$ February $\left(^{*}\right)$ & $6^{\text {th }}$ April $\left(^{*}\right)$ & $3^{\text {rd }}$ July $\left(^{* \star}\right)$ & $13^{\text {th }}$ September $\left(^{*}\right)$ \\
\hline 2012 & $11^{\text {th }}$ January $\left(^{* \star}\right)$ & $18^{\text {th }}$ May $\left(^{(\star}\right)$ & $21^{\text {st }}$ July $\left({ }^{* *}\right)$ & $10^{\text {th }}$ October $\left({ }^{*}\right)$ \\
\hline
\end{tabular}

Source: Own elaboration.

for the period January 2008 to December 2012. The images were downloaded from the Instituto Nacional de Pesquisas Espaciais (INPE, Brazil), United States Geological Survey (USGS, USA) and Comisión Nacional de Actividades Espaciales (CONAE, Argentina) websites (Table 1). The satellite images that presented cloud cover were discarded. The LANDSAT 7 ETM+ images error scan was corrected previously by applying the Scan Line Corrector technique (SCL-Off) (Pringle et al., 2009).

In addition, in situ air temperature $\left({ }^{\circ} \mathrm{C}\right)$, relative humidity (\%) and atmospheric pressure $(\mathrm{hPa})$ data were obtained from a meteorological station located in the city (Figure 1). The station was designed and built in the Instituto Argentino de Oceanografía (IADO-CONICET) and belongs to a net of coastal monitoring stations (Estaciones de Monitoreo Ambiental Costero, EMAC, $<$ http://emac.criba.edu.ar $>$ ). The parameters were used to adjust the atmospheric transition and the upwelling radiance to obtain the LST with the application of the NASA Atmospheric Correction Parameter Calculator (<http:// atmcorr.gsfc.nasa.gov/>).

A mono-channel algorithm was applied to obtain the LST, based on the radiative transfer equation (RTE) (Jimenez-Muñoz et al., 2009):

$$
L_{s e n}=\left[\varepsilon B\left(T_{s}+(1-\varepsilon) L_{d}\right)\right] \tau+L_{u} \quad[1]
$$

where $L_{\text {sen }}$ is the sensor radiance measurement $\left(\mathrm{W} \mathrm{m}^{-2} \mathrm{sr}^{-1} \mu \mathrm{m}^{-1}\right), \varepsilon$ is the surface emissivity, $\beta$ is the parameter derived from the Planck equation [2], $T$, is the land surface temperature $\left({ }^{\circ} \mathrm{K}\right), L_{d}$ is the downwelling atmospheric radiance $\left(\mathrm{W} \mathrm{m}{ }^{-2} \mathrm{sr}^{-1} \mu \mathrm{m}^{-1}\right), \tau$ is the atmospheric transmissivity, and $L_{u}$ is the upwelling atmospheric radiance $\left(\mathrm{W} \mathrm{m}^{-2} \mathrm{sr}^{-1} \mu \mathrm{m}^{-1}\right)$.

In order to obtain the LST, the direct inversion of the RTE is calculated (Jimenez-Muñoz et al., 2009):

$$
B\left(T_{s}\right)=\frac{\left(L_{s e n}-L_{u}-\tau(1-\varepsilon) L_{d}\right)}{\tau \varepsilon}
$$

Finally, the LST is obtained by applying the Plank law. This equation is based on the assumption that the energy is not continually transferred (JimenezMuñoz et al., 2009). To obtain the parameters to solve equation [1], a radio- 
metric calibration of the thermal band was performed. This correction is applied to satellite images to convert digital numbers to radiance values $\left(\mathrm{L}_{\lambda \text { sat }}\right)$ through:

$$
L_{\lambda s a t}=G_{\lambda} N D_{\lambda}+B_{\lambda}
$$

where $\lambda$ is the band number and $G_{\lambda}$ (Gain) and $B_{\lambda}$ (Biase) are the transforming coefficients of digital numbers to radiance values.

The surface emissivity was obtained on the assumption that the surface is heterogeneous in temperature and emissivity. The shadow influence was not considered. It is assumed that the system is Lambertian and that the temperature differences between the diverse parts of the system are not significantly dissimilar (Valor and Caselles, 1996).

$$
\varepsilon=\varepsilon_{v} P_{v}+\varepsilon_{s}\left(1-P_{v}\right)
$$

where $\varepsilon_{\nu}$ and $\varepsilon_{s}$ are the vegetation and soil emissivity, respectively. $P_{v}$ is the vegetation proportion and the calculation is based on the NDVI.

To estimate the NDVI, solar spectrum corrections were necessary. Thus, reflectivity was estimated considering a uniform Lambertian surface and with free cloud conditions according to the following equation (Schroeder et al., 2006):

$$
\rho_{\lambda S}=\frac{\left[\pi\left(L_{\lambda s a t}-L_{\lambda p}\right)\right]}{\left(T_{\lambda v}\left(E_{\lambda 0} d^{-2} \cos \Theta_{z} T_{\lambda z}+E_{\text {down }}\right)\right)}
$$

where $L_{\lambda p}\left(\mathrm{~W} \mathrm{~m}^{-2} \mathrm{sr}^{-1} \mu \mathrm{m}^{-1}\right)$ is the registered radiance as a result of the interaction between the electromagnetic radiation and the atmospheric components; $T_{\lambda_{\mathrm{V}}}$ is the atmospheric transmissivity from the surface to the sensor, $T_{\lambda z}$ is the atmospheric transmissivity in the direction of solar illumination, and $\mathrm{E}_{\text {down }}$ is the downwelling diffuse irradiance $\left(\mathrm{W} \mathrm{m}^{-2} \mathrm{um}^{-1}\right)$.

To calculate the parameters $L_{\lambda \mathrm{p}}, T_{\lambda v}, T_{\lambda z}$ and $\mathrm{E}_{\mathrm{down}}$, the Dark Object Subtraction method was applied (Song et al., 2001). This method is based on the assumption that pixels with a reflectivity close to zero (dark zones), such as clear or deep water and forests or shadow regions, are present in the image. It is possible to detect the atmospheric effects in these pixels (Carmona et al., 2011). To do so, it is necessary to subtract the $\mathrm{L}_{\lambda \mathrm{p}}$ value from each $\mathrm{L}_{\lambda \text { sat }}$ according to the following expression (Schroeder et al., 2006):

$$
L_{\lambda_{p}}=N D_{\lambda \text { dark }} G_{\lambda}+B_{\lambda}-0.01 \frac{\left(E_{\lambda 0} \cos _{\Theta z} T_{\lambda z} T_{\lambda y}\right)}{\left(d^{2} \pi\right)}
$$

where $N D_{\lambda \text { dark }}$ is the minimum $\mathrm{ND}_{\lambda}$ in each spectral band of each region of interest (a minimum of 1000 pixels). The method considers a Rayleigh atmo- 
sphere without aerosols and a surface reflectivity of $1 \%$ for the dark object (Carmona et al., 2011).

After atmospheric corrections were made in the visible bands, the NDVI was calculated:

$$
N D V I=\frac{N I R-R}{N I R+R} \quad[7]
$$

where $N I R$ is the near infrared band and $R$ is the red band.

Then, the proportion of vegetation $\left(\boldsymbol{P}_{v}\right)$ is obtained:

$$
P_{v}=\left[\frac{\left(N D V I-N D V I_{\text {min }}\right)}{\left(N D V I_{\max }-N D V I_{\text {min }}\right)}\right]^{2}
$$

where $N D V I_{\text {min }}$ is the NDVI bare soil value and $N D V I_{\max }$ is the maximum cover value (Carlson and Ripley, 1997). These parameters were calculated using the ENVI 4.5 software 2D scatter plot function.

Once the above parameters were calculated, atmospheric transition and the upwelling radiance data were used online (<http://atmcorr.gsfc.nasa.gov $>$ ). In this step, the time and date of the satellite image and pressure, height, air temperature and relative humidity of the moment are necessary. As a result, $\mathrm{L}_{\mathrm{u}}, \mathrm{L}_{\mathrm{d}}$ and $\tau$, were obtained to complete formula [1].

Once the LST values were obtained, thermal anomalies with two points (the first one located in the downtown, Point A; and the second in the periphery, Point B) were calculated to study the urban cold island. To achieve this objective, the thermal differences between Point A and B were considered for all the analyzed images (Figure 2) in order to dismiss the scanning errors. Then, with the LST values, a classification of urban land covers with empirical intervention (in two different transects) and visual interpretation of the diverse images (LANDSAT 5 TM and 7 ETM+ and Google Earth) were performed. As a result, a map of urban land covers was obtained (Figure 2). Other authors have successfully applied diverse land uses in urban spaces to study the distribution and variability of temperature. Bello Fuentes (1994), for example, studied the thermal air distribution (buildings, green areas, concrete, industry, and water) of Guadalajara, Spain, and detected heat islands in spots of the city whose intensity was related to the different land uses.

Finally, four transects (two latitudinal and two longitudinal) were determined over the obtained map (Figure 2). The transects were used to analyze the thermal behavior for the period 2008-2012 with the final objective of studying the seasonal variations of temperature in different urban covers (Table 2).

A statistical analysis was considered to establish a relationship between LST and NDVI. The determination coefficient $\left(\mathrm{R}^{2}\right)$ and correlation indexes 
Figure 2. Location of the urban land covers (codes for urban land cover explained in Table 1) and the thermal transects in the Monte Hermoso urban area. Long 1. Longitudinal Transect 1. Long 2. Longitudinal Transect 2. Lat 1. Latitudinal Transect 1. Lat 2. Latitudinal Transect 2

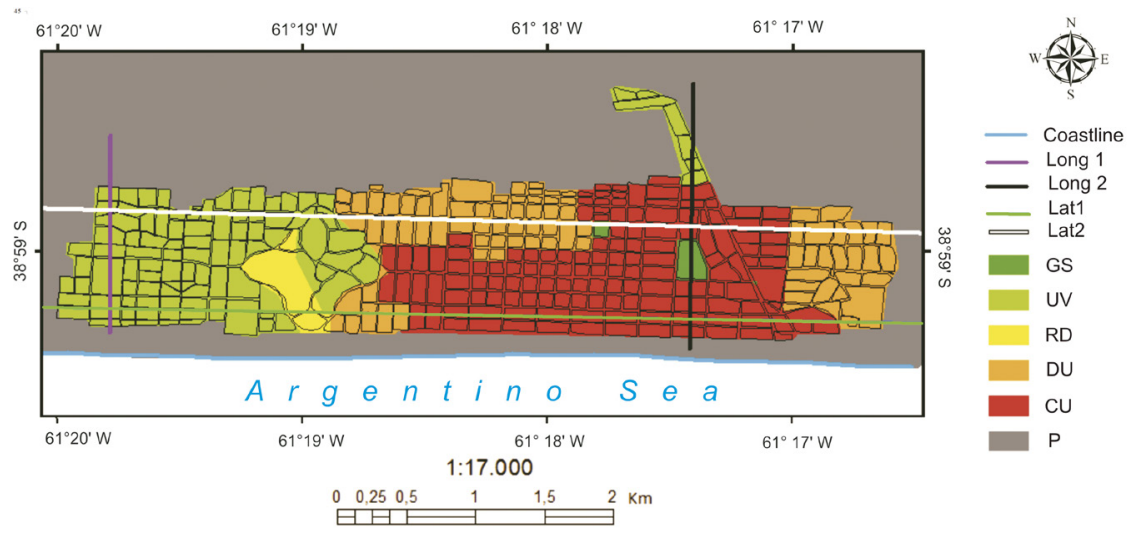

Source: Own elaboration.

Table 2. Urban land covers identified in Monte Hermoso city

\begin{tabular}{lrl}
\hline Urban land covers & \multicolumn{1}{c}{ Characteristics } \\
\hline Green spaces (GS) & 3 & Parks for recreational use \\
Urban with vegetation (UV) & $26 \begin{array}{c}\text { Sandy soils covered by dense arboreal vegetation with pres- } \\
\text { ence of dispersing buildings }\end{array}$ \\
$\begin{array}{l}\text { Relict dunes (RD) } \\
\text { Disperse-urban (DU) }\end{array}$ & $\begin{array}{l}\text { Dunes located in the urban area } \\
\text { Concentrated urban (CU) }\end{array}$ & $\begin{array}{c}\text { Uncovered soils with presence of herbaceous vegetation and } \\
\text { disperse buildings }\end{array}$ \\
Periphery (P) & 19 Senter of the city. Building concentration soils, dunes, beaches \\
\hline
\end{tabular}

Source: Own elaboration.

(Pearson and Spearman) were calculated and a regression analysis was performed considering a $\alpha$ of $10 \%$ and $5 \%$. Different surfaces of Monte Hermoso city were included for the analysis: Urban with vegetation (UV), Disperse-urban (DU), Relict dunes (RD) and Periphery (P) (Figure 2). Concentrated urban (CU) areas and Green spaces (GS) were not considered because shadows affect the accuracy of the parameters.

\section{Results}

\subsection{LST analysis}

During the study period, the spatial distribution of LST was not homogeneous. Generally, RD cover showed the higher temperatures, while CU land 
Figure 3. Spatial distribution of LST in Monte Hermoso for each season during the period 2008-2012
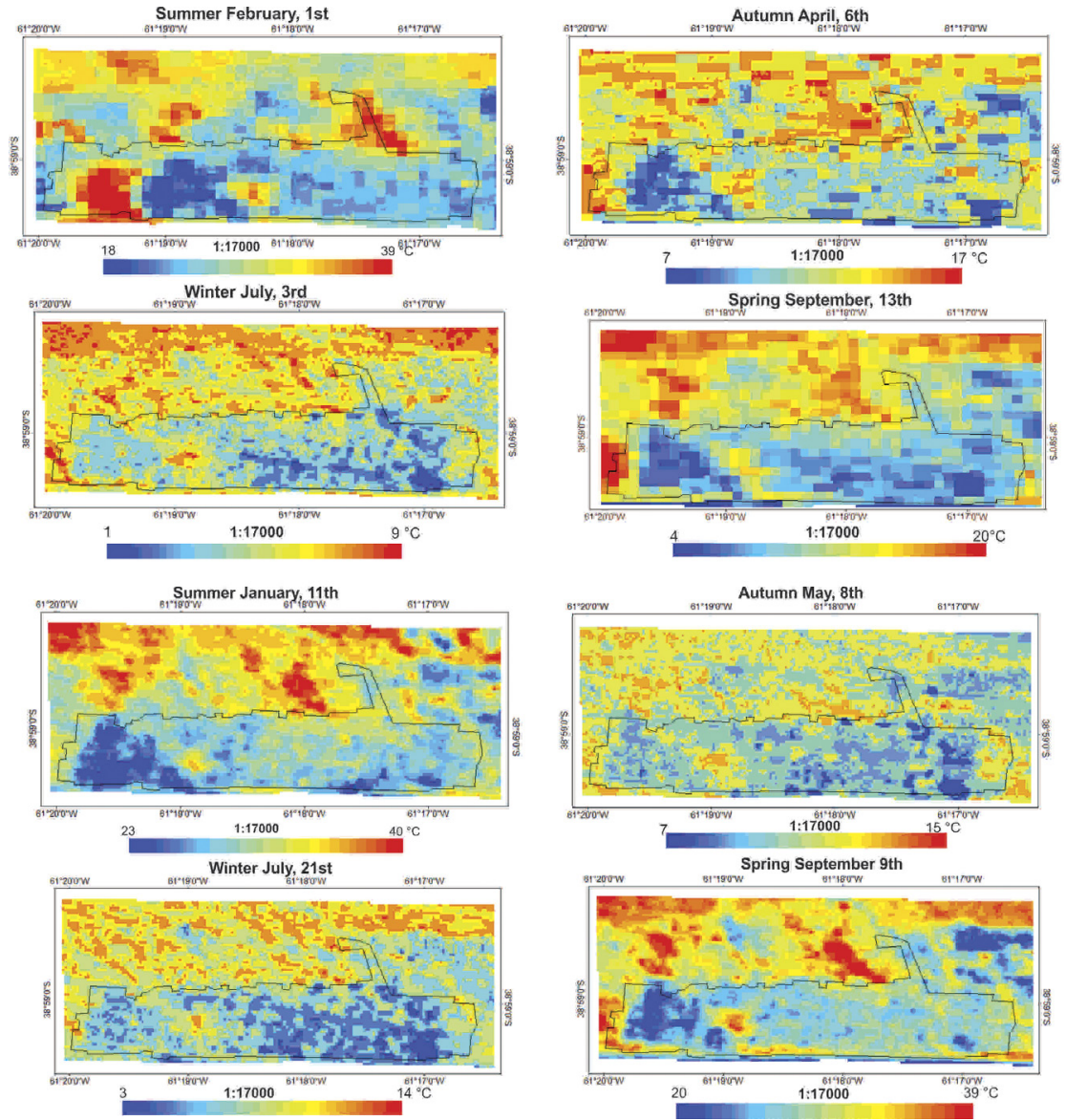

Source: Own elaboration.

cover registered the lowest ones. In the summer and autumn of 2008, the extension area of lower temperatures was higher than in winter and spring. On $8^{\text {th }}$ April, the LST showed the same behavior in the CU and UV covers. In this year, maximum values were recorded on $1^{\text {st }}$ January $\left(44^{\circ} \mathrm{C}\right)$ and minimum values on $11^{\text {th }}$ June, with temperatures close to $1^{\circ} \mathrm{C}$. In 2010 , the maximum temperature registered reached $47^{\circ} \mathrm{C}$ ( $6^{\text {th }}$ February) and the lowest one $4{ }^{\circ} \mathrm{C}$ (30 ${ }^{\text {th }}$ June). In 2011, the maximum temperature $\left(39^{\circ} \mathrm{C}\right)$ was observed on $1^{\text {st }}$ February and the minimum LST was registered on $3^{\text {rd }}$ July $\left(9{ }^{\circ} \mathrm{C}\right)$ (Figure 3). Finally, in 2012, maximum values of LST were observed in summer with $40{ }^{\circ} \mathrm{C}\left(11^{\text {th }}\right.$ January) and in spring, $39^{\circ} \mathrm{C}$ ( $7^{\text {th }}$ September $)$, while the minimum value was in winter with $3^{\circ} \mathrm{C}\left(21^{\text {st }} \mathrm{July}\right)$ (Figure 3$)$. 
Although the general tendency distribution indicates higher LST on the periphery of the city, it was possible to distinguish some differences depending on the time and the meteorological conditions. In the summer and autumn of 2010, the maximum LST values were observed in the southwest of the study area due to the displacement of living dunes. This is due to the fact that, at the satellite overpass time, sandy soils are warmer than the rest of the space (usually in the shadows of buildings or trees). Moreover, the results changed in spring due to vegetation foliage growth. The highest temperatures of the periphery were intensified by the north and northwest wind conditions, which generated dune sand movements on the edges of the city. In summer, the coldest areas coincided with the urban vegetation (parks and private residences).

The coastal urban climate is conditioned by the sea breezes, which cause low temperatures in the coastal areas. In Monte Hermoso, sea breezes mainly occur in summer characterized by winds coming from the south and southeast (Huamantinco Cisneros and Piccolo, 2011). In this context, the low temperatures in the coastal zone in spring 2008 were associated with the influence of the sea at high tide or at midday with low tide and the wet sand.

\subsection{Thermal amplitudes}

At satellite overpass time for Monte Hermoso (10:45 a.m. local time, approximately), it was found that the periphery was warmer than the downtown. While the downtown is cooler in the morning due to shadow effect, the periphery is being heated by the sun. Although the LST pattern was always the same, with a relatively "cold" center and a relatively "warm" periphery, seasonal differences were found. During the study period, the LST amplitude was higher in summer (mean thermal amplitude: $15^{\circ} \mathrm{C}$ ) and spring (mean thermal amplitude: $13.8^{\circ} \mathrm{C}$ ). The lowest thermal amplitudes were registered in winter (mean thermal amplitude: $7^{\circ} \mathrm{C}$ ), while autumn showed an intermediate behavior with a mean thermal amplitude of $10.4^{\circ} \mathrm{C}$. As an example, in 2008 the maximum amplitude was registered on $6^{\text {th }}$ October $\left(14.6^{\circ} \mathrm{C}\right)$ and the minimum on $10^{\text {th }}$ June $\left(6^{\circ} \mathrm{C}\right)$ (Figure 4$)$. The maximum thermal amplitude of the study period was on $1^{\text {st }}$ February 2011 , with $20.9^{\circ} \mathrm{C}$. In 2008, 2009 and 2012, the thermal amplitude was higher in spring than in summer, while the amplitude was higher in summer than in spring in 2010 and 2011.

\subsection{NDVI-LST analyses}

A close inverse relationship was found between the NDVI and LST parameters. The mean maximum NDVI value was found on $21^{\text {st }}$ July $2012(0.59)$ and the

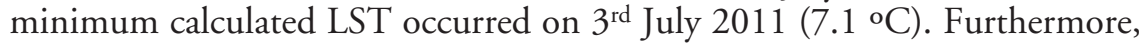
the highest NDVI registers were observed in winter and the minimum during summer, while the LST parameter showed the opposite behavior (Table 3). For example, summer and spring (the warmest seasons with a mean LST of 33.5 and $26.6^{\circ} \mathrm{C}$, respectively) registered the lowest NDVI values (0.32 and 
Figure 4. LST amplitude in Monte Hermoso for the period 2008-2012 obtained from LANDSAT $5 \mathrm{TM}$ and $7 \mathrm{ETM}+$ processing

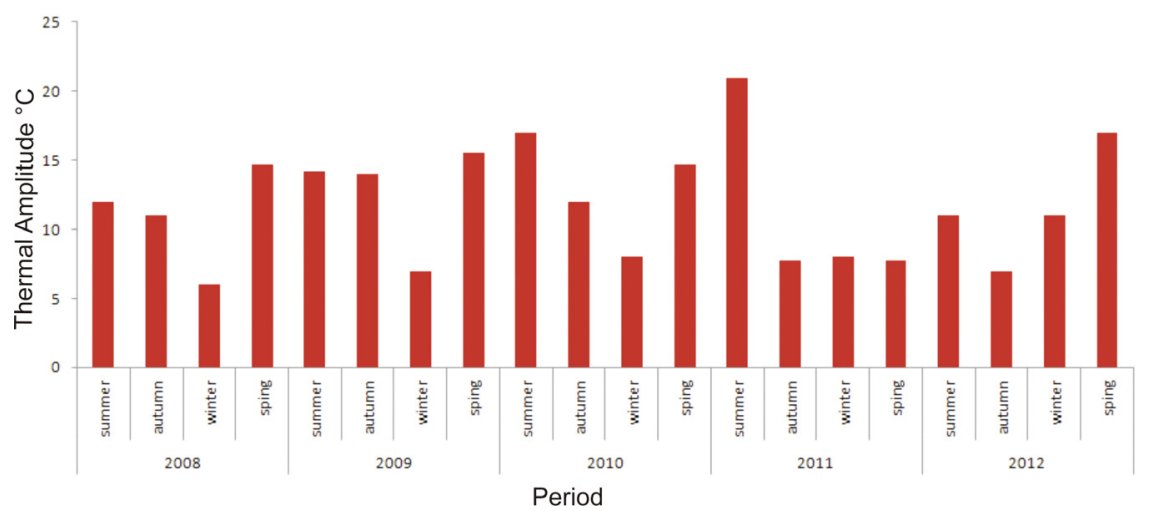

Source: Own elaboration.

Table 3. Mean, maximum (max), minimum (min) and standard deviation (SD) of NDVI and LST values

\begin{tabular}{|c|c|c|c|c|c|c|c|c|c|}
\hline \multirow[b]{2}{*}{ Years } & \multirow[b]{2}{*}{ Dates } & \multicolumn{4}{|c|}{ NDVI } & \multicolumn{4}{|c|}{ LST } \\
\hline & & Mean & Max & Min & SD & Mean & Max & Min & SD \\
\hline \multirow[t]{4}{*}{2008} & $2^{\text {nd }}$ February & 0.23 & 0.635 & 0.01 & 0.1 & 34.6 & 37.5 & 31.8 & 1.62 \\
\hline & $21^{\text {st }}$ April & 0.4 & 0.671 & 0.05 & 0.18 & 21.6 & 26.7 & 18.5 & 2.63 \\
\hline & $8^{\text {th }}$ June & 0.52 & 0.895 & 0.01 & 0.24 & 7.8 & 1.6 & 8.4 & 1.49 \\
\hline & $6^{\text {th }}$ October & 0.3 & 0.63 & 0.09 & 0.18 & 33.4 & 28.9 & 40.4 & 2.12 \\
\hline \multirow[t]{4}{*}{2009} & $10^{\text {th }}$ January & 0.31 & 0.51 & 0.09 & 0.1 & 35.4 & 28.1 & 40.8 & 2.56 \\
\hline & $8^{\text {th }}$ April & 0.44 & 0.89 & 0.03 & 0.25 & 21.9 & 40.1 & 19.1 & 2.7 \\
\hline & $11^{\text {th }}$ June & 0.34 & 0.89 & 0.1 & 0.15 & 10.5 & 12.1 & 2.7 & 1.86 \\
\hline & $26^{\text {th }}$ November & 0.31 & 0.58 & 0.1 & 0.14 & 34.2 & 26.2 & 41.6 & 2.73 \\
\hline \multirow[t]{4}{*}{2010} & $6^{\text {th }}$ February & 0.16 & 0.33 & 0.003 & 0.09 & 36.5 & 31.3 & 44.3 & 2.32 \\
\hline & $27^{\text {th }}$ April & 0.44 & 0.708 & 0.08 & 0.18 & 19.3 & 16.23 & 24.45 & 2.63 \\
\hline & $30^{\text {th }}$ June & 0.524 & 0.81 & 0.114 & 0.2 & 11.2 & 2.6 & 13.4 & 2.12 \\
\hline & $12^{\text {th }}$ October & 0.35 & 0.619 & 0.07 & 0.2 & 26.7 & 32.4 & 20.9 & 3.12 \\
\hline \multirow[t]{4}{*}{2011} & $1^{\text {st }}$ February & 0.45 & 0.95 & 0.14 & 0.29 & 30.1 & 38.4 & 18.7 & 2.63 \\
\hline & $6^{\text {th }}$ April & 0.48 & 0.937 & 0.085 & 0.17 & 23.6 & 32.2 & 17.5 & 2.35 \\
\hline & $3^{\text {rd July }}$ & 0.53 & 0.08 & 0.75 & 0.2 & 7.1 & 8.7 & 4.5 & 1.21 \\
\hline & $13^{\text {th }}$ September & 0.34 & 0.585 & 0.12 & 0.13 & 13.1 & 16.8 & 7.6 & 2.95 \\
\hline \multirow[t]{4}{*}{2012} & $11^{\text {th }}$ January & 0.44 & 0.78 & 0.1 & 0.22 & 30.9 & 39.4 & 25 & 3.43 \\
\hline & $18^{\text {th }}$ May & 0.57 & 0.86 & 0.17 & 0.14 & 12.4 & 14.3 & 9.9 & 1.02 \\
\hline & $21^{\text {st }}$ July & 0.59 & 0.93 & 0.15 & 0.2 & 10.4 & 13.4 & 8.7 & 1.2 \\
\hline & $10^{\text {th }}$ October & 0.37 & 0.64 & 0.09 & 0.2 & 25.4 & 31.1 & 19.4 & 3.19 \\
\hline
\end{tabular}

Source: Own elaboration. 
Table 4. Seasonal values of mean NDVI and mean LST

\begin{tabular}{lcc}
\hline Season & Mean NDVI & Mean LST \\
\hline Summer & 0.32 & 33.5 \\
Autumn & 0.47 & 19.8 \\
Winter & 0.51 & 9.4 \\
Spring & 0.33 & 26.6 \\
\hline
\end{tabular}

Source: Own elaboration.

Table 5. Mean NDVI and LST values for each urban land cover for the period 2008-2012

\begin{tabular}{lcc}
\hline \multicolumn{1}{c}{ Urban land covers } & Mean NDVI & Mean LST \\
\hline Green spaces & 0.62 & 19.3 \\
Urban with vegetation & 0.52 & 20.1 \\
Relict dunes & 0.18 & 26.2 \\
Disperse-urban & 0.27 & 23.1 \\
Concentrated urban & 0.25 & 21.2 \\
Periphery & 0.32 & 24.6 \\
\hline
\end{tabular}

Source: Own elaboration.

0.33 , respectively). Autumn presented intermediate values (NDVI 0.47 and LST $\left.19.8^{\circ} \mathrm{C}\right)$, while winter was the coldest season $\left(9.4^{\circ} \mathrm{C}\right)$ with the highest NDVI values (0.51) (Table 4).

A relationship between the vegetation density and the spatial distribution of NDVI and LST was also found. In GS and UV, the NDVI was higher than in the other urban covers (0.67 and 0.52 , respectively), and the lowest LSTs were observed $\left(19.3\right.$ and $20.1^{\circ} \mathrm{C}$, respectively). RD presented minimum NDVI values $(<0.2)$, DU $(<0.3)$ and $\mathrm{CU}(<0.3)$ and also the highest LST values $\left(26.2,23.1\right.$ and $21.2^{\circ} \mathrm{C}$, respectively) (Table 5). In all urban land uses, most of the NDVI and LST fluctuations are caused by shadows, the buildings, and the vegetation density. The maximum NDVI oscillations were observed in the CU cover, which was produced by high building density and low vegetation abundance. As an example, the results obtained on $1^{\text {st }}$ February 2011 are shown in Figure 5.

\subsection{LST-NDVI relationship}

In Monte Hermoso city, a close relationship was found between LST and NDVI $\left(\mathrm{R}^{2}>0.7\right)$. Generally, the NDVI-LST regression showed an accurate fit. Higher $\mathrm{R}^{2}$ values were observed in autumn and spring $(>0.8)$ and lower ones in summer and winter $\left(0.8>\mathrm{R}^{2}<0.7\right)$. The highest $\mathrm{R}^{2}$ was 0.93 and was observed on $6^{\text {th }}$ April 2011 and the lowest one was 0.51 (10 $0^{\text {th }}$ June 2009). The Pearson and Spearman correlation coefficients also demonstrate the relationship between both variables. In all cases, the Pearson and Spearman indexes were higher than 0.7 and ranged from 0.72 to 0.98 and 0.73 to 0.96 , respec- 
Figure 5. Representative NDVI spatial distribution in the different land covers in Monte Hermoso city (1st February 2011)



PIXEL VALUES

Source: Own elaboration.

Figure 6. NDVI and LST relationship at different dates in the period 2008-2012
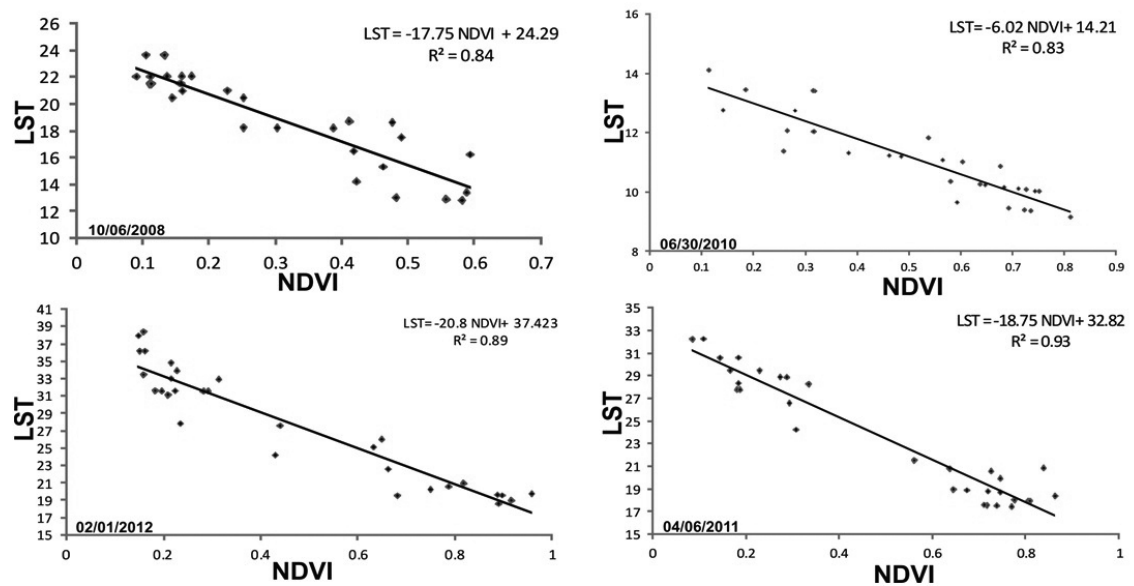

Source: Own elaboration. 
Table 6. NDVI-LST relationship

\begin{tabular}{|c|c|c|c|c|}
\hline Years & Dates & $\mathrm{R}^{2}$ & $P$ & $S$ \\
\hline \multirow[t]{4}{*}{2008} & $2^{\text {nd }}$ February $\left(^{*}\right)$ & 0.62 & 0.79 & 0.87 \\
\hline & $21^{\text {st }}$ April $\left({ }^{\star \star}\right)$ & 0.86 & 0.93 & 0.94 \\
\hline & $8^{\text {th }}$ June $\left(^{\star \star}\right)$ & 0.79 & 0.89 & 0.90 \\
\hline & $6^{\text {th }}$ October $\left(^{* \star}\right)$ & 0.85 & 0.92 & 0.87 \\
\hline \multirow[t]{4}{*}{2009} & $10^{\text {th }}$ January $\left(^{*}\right)$ & 0.51 & 0.72 & 0.73 \\
\hline & $8^{\text {th }}$ April $\left(^{* \star}\right)$ & 0.76 & 0.87 & 0.86 \\
\hline & $11^{\text {th }}$ June $\left(^{*}\right)$ & 0.73 & 0.79 & 0.81 \\
\hline & $26^{\text {th }}$ November $\left.{ }^{(*}\right)$ & 0.88 & 0.94 & 0.91 \\
\hline \multirow[t]{4}{*}{2010} & $6^{\text {th }}$ February $(*)$ & 0.72 & 0.85 & 0.82 \\
\hline & $27^{\text {th }}$ April $\left(^{\star \star}\right)$ & 0.86 & 0.93 & 0.94 \\
\hline & $30^{\text {th }}$ June $\left(^{* \star}\right)$ & 0.87 & 0.93 & 0.94 \\
\hline & $12^{\text {th }}$ October $\left(^{\star \star}\right)$ & 0.78 & 0.88 & 0.76 \\
\hline \multirow[t]{4}{*}{2011} & $1^{\text {st }}$ February $\left(^{\star \star}\right)$ & 0.89 & 0.91 & 0.92 \\
\hline & $6^{\text {th }}$ April (**) & 0.93 & 0.98 & 0.96 \\
\hline & $3^{\text {rd July }}\left(^{\star \star}\right)$ & 0.79 & 0.81 & 0.82 \\
\hline & $13^{\text {th }}$ September $(*)$ & 0.71 & 0.75 & 0.73 \\
\hline \multirow[t]{4}{*}{2012} & $11^{\text {th }}$ January $\left(^{* *}\right)$ & 0.77 & 0.83 & 0.81 \\
\hline & $18^{\text {th }}$ May $\left(^{* *}\right)$ & 0.75 & 0.72 & 0.73 \\
\hline & $21^{\text {st }}$ July $\left(^{*}\right)$ & 0.71 & 0.81 & 0.74 \\
\hline & $10^{\text {th }}$ October $\left(^{\star *}\right)$ & 0.78 & 0.83 & 0.82 \\
\hline
\end{tabular}

Note: $\mathrm{P}=$ Pearson; $\mathrm{S}=$ Spearman; $\left({ }^{*}\right)$ regression analysis significant with an $\alpha=0.1 ;\left({ }^{* *}\right)$ regression analysis significant with an $\alpha<0.05$

Source: Own elaboration.

tively (Table 6). Minor adjustments were found on summer days; for example on $2^{\text {nd }}$ February $2008\left(\mathrm{R}^{2} 0.62\right)$ and on $10^{\text {th }}$ January $2009\left(\mathrm{R}^{2} 0.51\right)$. Furthermore, four examples of different dates and seasons are presented in Figure 6 . In these cases, the results of the regression analyses were highly significant $(p<0.01)$. A constant pattern was observed for the urban land cover. In the $\mathrm{RD}$ and P land covers, the highest LST values and the lowest NDVI values were registered. The DU zone presented an intermediate situation of both variables, while the highest NDVI and the lowest LST values were found for UV.

Minimum NDVI values were associated to bare soils without vegetation (RD and $\mathrm{P})$. In areas where high LST values were observed, the NDVI diminished due to the variation in vegetation state or abundance. This is related to changes in the natural cycle of vegetation or to diverse human activities (e.g., tourism influx, increase in vehicle circulation). Maximum temperatures were registered in areas with bare soils and urban growing spaces.

In summer 2011, two sectors which presented a different LST thermal behavior were analyzed. The differences were observed in the distribution of maximum temperatures. Changes in LST were identified, with a maximum of $39{ }^{\circ} \mathrm{C}$ in the northeast (Sector 1) and southwest (Sector 2) of the city (Figure 7) where an intense degradation of vegetation cover was observed. 
Figure 7. Urban scheme of land cover in two specific sectors of Monte Hermoso where changes in LST were detected
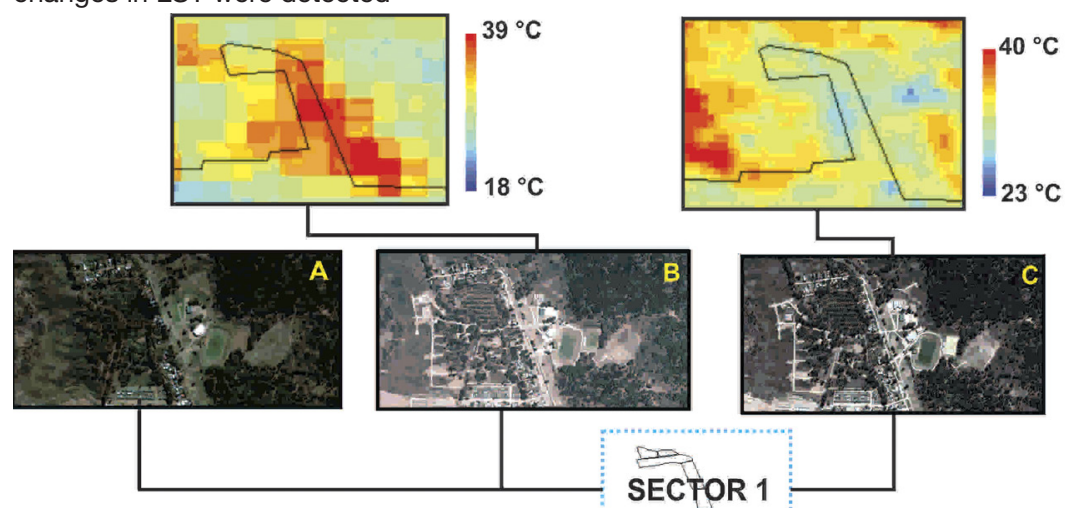

SECFOR 1
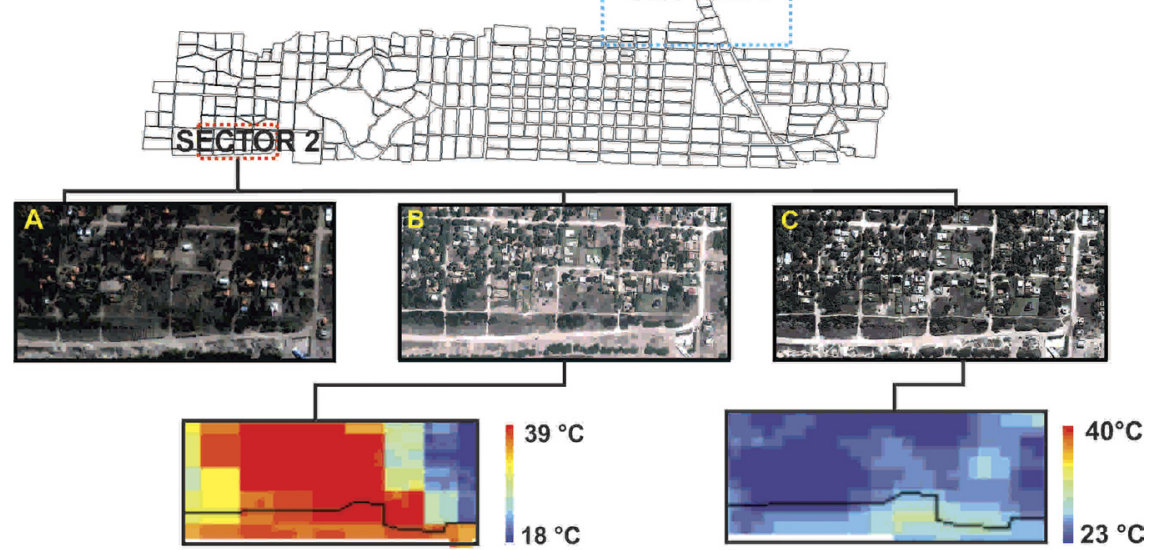

Sector 1: A) 2007, B) 2011 and C) 2012. Sector 2: A) 2004, B) 2011 and C) 2012. 2004 and 2007 represent the LST distribution before the studied period. The selection of images depended on the availability of Google Earth

Source: Own elaboration.

Lot division and cut trees (in the southwest of the city) and intensive vehicle circulation due to tourism activities (in the northeast of the city) were identified. These activities produced vegetation cover degradation and an increase in LST. As mentioned before, changes in land cover are one of the main drivers of modifications in city temperature. In addition, an increase in the number of buildings directly changes wind speed and increases turbulence, thus affecting the temperature distribution (Sepulveda Moreno, 2006). In Monte Hermoso, these changes produced a difference in LST of $9.8^{\circ} \mathrm{C}$ (Sector 1 ) and $16.1^{\circ} \mathrm{C}$ (Sector 2) between 2011 and 2012. In the latter year, the vegetation cover increased, producing a decrease in LST values (Figure 7). 


\subsection{Thermal transects}

The most representative latitudinal and longitudinal thermal transects of the study are presented. In the latitudinal transects, maximum LST variations related to the soil covers were observed in summer (Figure 8). In spring and autumn, the LST behavior was similar to the summer or winter thermal tran-

Figure 8. Latitudinal transect 1 for winter and summer of 2011 (transect is shown in Figure 2).

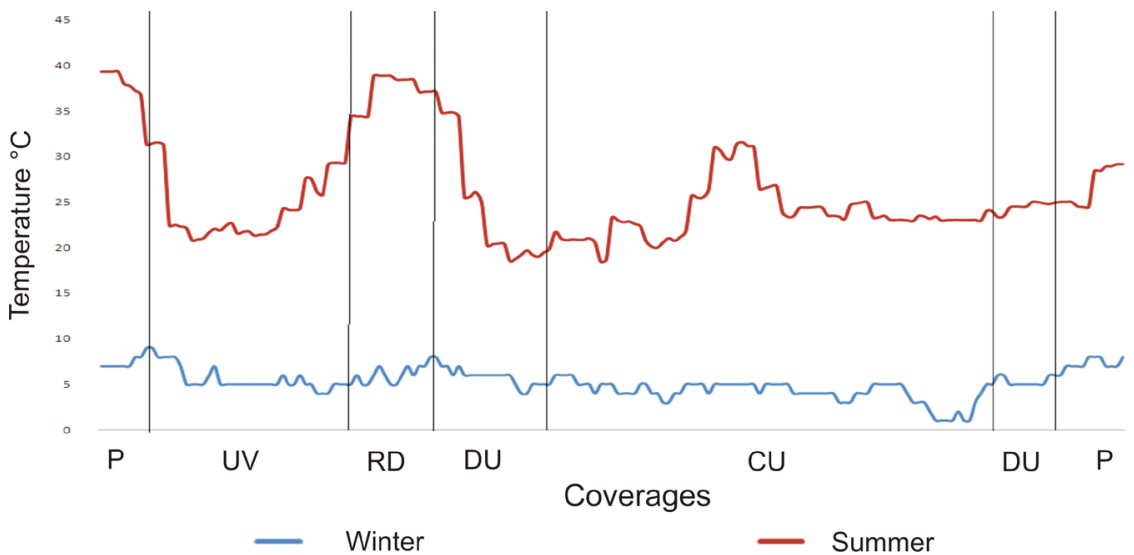

$\mathrm{P}=$ Periphery; $\mathrm{DU}=$ Disperse-urban; $\mathrm{UV}=$ Urban with vegetation; $\mathrm{RD}=$ Relict dunes and $\mathrm{CU}=$ Concentrated urban

Source: Own elaboration.

Figure 9. Latitudinal transect 2 for autumn and spring of 2012 (transect is shown in Figure 2)

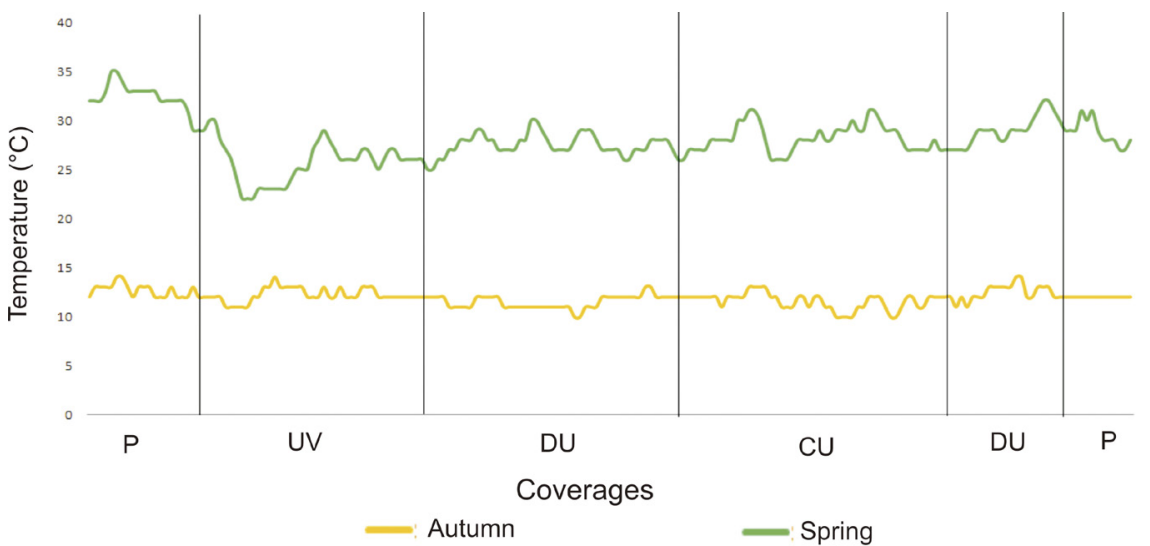

$\mathrm{P}=$ Periphery $\mathrm{DU}=$ Disperse-urban; $\mathrm{UV}=$ Urban with vegetation; $\mathrm{RD}=$ Relict dunes and $\mathrm{CU}=$ Concentrated urban

Source: Own elaboration. 
sects depending on the meteorological conditions of the measurement day and the information provided by the satellite image. Finally, winter showed a homogeneous behavior in the study area. Maximum values were observed in the latitudinal transects of the RD and P land uses (Figure 8 and 9).

LST variations in the UV cover were not significant. Minimum values were registered in the $\mathrm{CU}$ area due to the presence of shadows, while maximum LST values were observed in the DU areas due to the high presence of bare soils (Figure 8).

Even though the longitudinal transects include diverse soils covers, the seasonal behavior did not show significant changes in the studied period. The lower values registered in transect 2 are in accordance with the presence of a dense vegetation cover observed in the UV. During summer, maximum LST values were registered in the $\mathrm{P}$ area, which is characterized by the high presence of sandy soils. The UV cover presented variations only when the vegetation cover changed (Figure 8 and Figure 9).

\section{Discussion}

This study has analyzed five consecutive years of land surface temperature in a coastal and tourist city. The results indicated that the periphery of Monte Hermoso was warmer than the city's downtown area. According to Valor et al. (2000), the periphery is warmer in the morning because the city is affected by building shadows, while the periphery is heated by the sun. Furthermore, the absence of vegetation in the periphery does not mitigate the solar heat (Dimoudi and Nikolopoulou, 2003), while inside the urban area the shadow produced by vegetation also mitigates the urban heat island effect. The shadows reduce the long wave radiation and hence the LST. In addition, vegetation increases the latent cooling by providing humidity to the atmosphere through evapotranspiration processes (Dimoudi and Nikolopoulou, 2003). The thermal amplitudes of Monte Hermoso were higher in the summer $\left(10-22^{\circ} \mathrm{C}\right)$. These results are in line with those of Kolokotsa et al. (2009), who reported that medium-sized coastal cities present stronger thermal amplitudes during summer.

As expected, a close relationship was found between LST and NDVI $\left(\mathrm{R}^{2}\right.$ higher than 0.7 ). This is determined by the quantity of vegetation, thus NDVI could be used as an indicator of LST variability (Goetz et al., 2000). In areas with vegetation cover, the radiative temperature registered by the satellite sensor has been found to better approximate the in situ temperature (Goward et al., 2002). Vegetation cover also shows high-temperature variations since thermal responses depend on the biophysical characteristics of the different species (Quattrochi and Ridd, 1998). This was observed in Monte Hermoso where the urban vegetation (UV) land cover presented the highest variability, while the lowest variations were identified in relict dunes $(\mathrm{RD})$ and concentrated urban $(\mathrm{CU})$ areas. However, it is worth highlighting that LST is affected by urban expansion and that vegetation is considered an important mitigation factor of urban heat island intensity (Sarricolea et al., 2006; Oltra-Carrió et al., 2010). 
Cities are constantly growing and produce impacts on the urban micro-climate, which affect the health of the population, urban ecosystems, water resources and access (Vilani and Sanchez, 2013). Therefore, urban planning has emerged as a tool to address the current situation. The urban climate is a limiting factor for urban development as it can expose citizens to situations of risk due to excessive heat, cold, floods, and others (Cuadrat et al., 2014). The Intergovernmental Panel on Climate Change (IPCC, 2014) has warned that air temperature will increase on a global scale. This situation will be more intense in cities due to the increase in urban heat islands. For this reason, the study of urban climate is a fundamental issue to prevent possible changes and define adaptation strategies. Cities emit the largest amount of greenhouse gases and are an artificial source of heat. Land management should be oriented to the development of adequate infrastructure, the provision of potable water, the comfort of citizens and health benefits (Cuadrat et al., 2014).

Currently, coastal cities are one of the main drivers of environmental degradation and contribute to intensify the climate change (Sekovsky et al., 2012). In this sense, Monte Hermoso is an example of this situation. Tourism activities in coastal cities need to constantly change their internal structure because they must promote and ensure tourism (Calvento and Colombo, 2009). In 2012, Argentina was the main tourist destination in South America and saw a $362 \%$ increase in domestic tourism from 2002 to 2012 (Vera, 2013). This increase in tourists required more urban space, thus local government and private business modified and orientate the urban growth (Vera, 2013). In Monte Hermoso city, the selection of the urban space is related to the availability of tourist services (hotels, restaurants and entertainment venues, among others). For this reason, the most concentrated and changed spaces have been those located in the city center and in their access area (where other tourism services are available such as campsites or quad bike rentals). Stakeholders are responsible for maintaining urban traditions and preserving the urban landscape (Ornés, 2009). Therefore, it is essential that each city has a land use plan to orient policies to improve the relationship between society and space (Ornés, 2009).

The case of Monte Hermoso city highlights the importance of sustainable urban planning that benefits natural resources, ensures citizens' well-being, and improves the urban climate conditions. In Monte Hermoso, the experiences of different stakeholders and decision makers can provide interesting information about how they perceive the urban changes and how such changes affect them. This will be another step to take in order to reach a full understanding of the urban condition. The information presented in this paper would be useful and should be considered for future studies concerning urban planning in coastal tourist cities. The active participation of these groups will permit the development of urban plans and their cohesion as a community.

\section{Conclusions}

Monte Hermoso city has become of the most important coastal tourist centers of Buenos Aires Province (Argentina). The LST distribution of Monte Her- 
moso was characterized by a warmer periphery and a cooler city center, mainly in summer and spring. In winter, the differences between the center and the periphery presented a thermal amplitude lower than $7^{\circ} \mathrm{C}$ and a homogeneous distribution, despite the land cover.

The relationship between LST and NDVI highlights the importance of vegetation in the urban center, since the abundance of vegetation leads to a homogeneous distribution of LST. Changes in natural land covers due to urban growth modify LST behavior, as observed in the summers of 2011 and 2012.

This study reinforces the importance of remote sensing as a valuable tool for urban climate analysis. Determining LST behavior associated with vegetation distribution has become a key factor in understanding urban environmental dynamics and contributing to responsible urban planning.

\section{Acknowledgments}

The authors would like to thank the Consejo Nacional de Investigaciones Científicas y Técnicas (CONICET, Argentina) and the Universidad Nacional del Sur for supporting this study. They are also grateful to the Instituto Argentino de Oceanografía (IADO, Argentina), the United States Geological Survey, the Instituto Nacional de Pesquisas Espaciais, the Comisión Nacional de Actividades Espaciales and the Instituto Nacional de Estadísticas y Censos for providing the information analyzed in this work.

\section{Bibliographical references}

Bello Fuentes, V. (1994). "La isla de calor y los usos del suelo en Guadalajara”. Serie Geográfica, 4, 83-97.

Calvento, M. and Colombo, S. (2009). "La marca-ciudad como herramienta de promoción turística ¿iinstrumento de inserción nacional e internacional?”. Estudios y perspectivas en Turismo, 18, 262-284.

CARLSON T. N. and Ripley D. A. (1997). "On the relation between NDVI, fractional vegetation cover, and leaf area index”. Remote Sensing of Environment, 62, 241-252. <https://doi.org/10.1016/S0034-4257(97)00104-1>

Carmona, F., Rivas, R., Thomas, L. and Marino, B. (2011) "Caracterización espectral del estuario del río Quequén Grande por medio de imágenes Landsat” In: R. Rivas, F. CARMONA and D. OCAMPO (eds.). Teledetección. Recientes aplicaciones en la región pampena. Mar de Plata: Editorial Martín.

Chen, X.-L., ZHAO, H.-M., Li, P.-X. and Yin, Z.-Y. (2006). "Remote sensing imagebased analysis of the relationship between urban heat island and land use/cover changes." Remote Sensing of Environment, 104, 133-146. <https://doi.org/10.1016/j.rse.2005.11.016>

Chiementon, M. E. and Cogliati, M. G. (2011). "Variaciones del uso del suelo en Cipolletti, Provincia de Río Negro, Argentina". Contribuciones Científicas GAEA, 23, 51-60.

Comisión Nacional de Actividades Espaciales (CONAE). <http://www.conae. gov.ar> [Retrieved $15^{\text {th }}$ October 2015]. 
Cuadrat, J. M., Saz, M. A., Serrano, R. and Tejedor, E. (2014). "El clima del término municipal de Zaragoza en el contexto del cambio global”. In: Departamento de Geografía y Orientación del Territorio. Zaragoza: Universidad de Zaragoza.

Cúnsulo, M. E., Kurbán, A. and Hermes Papparelli, A. (2012). "Inferencia de la temperatura del aire urbano a partir del NDVI utilizando imágenes satelitales". Avances en Energías Renovables y Medio Ambiente, 16, 11.01-11.07.

Crutzen, P. J. (2004). "New directions: The growing urban heat and pollution 'island' effect-Impact on chemistry and climate". Atmospheric Environment, 38, 3539-3540. <http://doi.org/10.1016/S1352-2310(04)00297-3>

Deosthali, V. (1999). "Assessment of impact of urbanization on climate: an application of bio-climatic index". Atmospheric Environment, 33, 4125-4133. <http://doi.org/10.1016/S1352-2310(99)00154-5>

Deosthali, V. (2000). "Impacts of rapid urban growth on heat and moisture islands in Pune City, India”. Atmospheric Environment, 34, 2745-2754. <https://doi.org/10.1016/S1352-2310(99)00370-2>

Dimoudi, A. and Nikopoulou, M. (2003). "Vegetation in the urban environment: microclimatic analysis and benefits". Energy and Buildings, 35, 69-76. <https://doi.org/10.1016/S0378-7788(02)00081-6>

Estaciones de Monitoreo Ambiental COSTERo (EMAC). Instituto Argentino de Oceanografía. IADO-CONICET. <http://emac.criba.edu.ar/> [Retrieved October $20^{\text {th }} 2015$ ].

Ferrelli, F., Bustos, M. L., Huamantinco Cisneros, M. A. and Piccolo, M. C. (2015). "Utilización de imágenes satelitales para el estudio de la distribución térmica en distintas coberturas del suelo de la ciudad de Bahía Blanca (Argentina)". Revista de Teledetección, 44, 31-42. <http://doi.org/10.4995/raet.2015.4018>

GARCIA, M. C. (2009). El clima urbano costero de la zona atlántica comprendida entre $37^{\circ} 40^{\prime}$ y $38^{\circ} 50^{\prime} S$ y 57 y $59^{\circ} \mathrm{W}$. PhD Thesis Department of Geography and Tourism, Universidad Nacional del Sur, Argentina.

Goetz, S., Prince, S. and Small, J. (2000). "Advances in Satellite Remote Sensing of Environmental Variables for Epidemiological Application”. Advances in Parasitology, 47, 289-307. <https://doi.org/10.1016/S0065-308X(00)47012-0>

Goward, S. N., Xue, Y. and CzajKowski, K. P. (2002). "Evaluating landsurface moisture conditions from the remotely sensed temperature/vegetation index measurements: An exploration with the simplified simple biosphere model". Remote Sensing of Environment, 79, 225-242. <https://doi.org/10.1016/S0034-4257(01)00275-9>

GrimmOND, S. (2007). "Urbanization and global environmental change: local effects of urban warming". Geographical Journal, 173, 83-88. <https://doi.org/10.1111/j.1475-4959.2007.232_3.x>

HuAmantinCo Cisneros, M. A. (2012). Efecto de la variabilidad climática del balneario Monte Hermoso sobre su geomorfología costera y el confort climático. $\mathrm{PhD}$ Thesis Department of Geography and Tourism, Universidad Nacional del Sur, Argentina.

Huamantinco Cisneros, M. A. and Piccolo, M. C. (2011). "Caracterización de la brisa de mar en el balneario de Monte Hermoso, Argentina”. Estudios Geográficos, 271, 461-475. <https://doi.org/10.3989/estgeogr.201118>

INDEC (Instituto Nacional de Estadística y Censos). <https:/www.indec.gov.ar/nivel4_default. asp?id_tema_1=28id_tema_2=418id_tema_3=135> [Retrieved $22^{\text {th }}$ January 2018]. 
INPE (Instituto Nacional de Pesquisas Espaciais). <http://www.inpe.br/> [Retrieved $15^{\text {th }}$ October 2014].

IPCC (Intergovernmental Panel on Climate Change. "Climate Change 2014: Synthesis Report" <www.ipcc.ch> [Retrieved 16 $6^{\text {th }}$ October 2014].

Jimenez-Muñoz, J. C., Cristobal, J., Sobrino, J. A., Soria, G., Ninyerola, M. and PONS, X. (2009). "Revision of the single-channel algorithm for lands surface temperature retrieval from Landsat thermal-infrared data". IEEE Transactions on Geoscience and Remote Sensing, 47, 339-349. <https://doi.org/10.1109/TGRS.2008.2007125>

Kaufmann, R. K., Seto K. C., Shneider, A., Liu, Z., Zhou, L. and Wang, W. (2007). "Climate response to rapid urban growth: evidence of human-induced precipitation deficit". Journal of Climate, 20, 2299-2306. <https://doi.org/10.1175/JCLI4109.1>

KIM, Y.-H. and BAIK J.-J. (2004). "Spatial and temporal structure of the urban heat island in Seoul". Journal of Applied Meteorology, 44, 591-605. <https://doi.org/10.1175/JAM2226.1>

Kolokotsa, D., Psomas, A. and Karapidakis, E. (2009). "Urban heat island in southern Europe: the case study of Hania, Crete”. Solar Energy, 83, 1871-1883. <https://doi.org/10.1016/j.solener.2009.06.018>

NASA AtMospheric Correction PARAmeter CAlCulator. <http://atmcorr.gsfc. nasa.gov/> [Retrieved 30 ${ }^{\text {th }}$ October 2015].

Oltra-Carrio, R., Sobrino, J. A., Gutiérrez-Angonese, J., Gioia, A., Paolini, L. and MaliziA, A. (2010). "Estudio del crecimiento urbano, de la estructura de la vegetación y de la temperatura de la superficie del Gran San Miguel de Tucumán, Argentina". Revista de Teledetección, 69-76.

ORNÉS, S. (2009). "El urbanismo, la planificación urbana y el ordenamiento territorial desde la perspectiva del derecho urbanístico venezolano”. Revista Politeia, 42 (32), 197-225.

PATAKi D. E., Bowling D. R. and Ehleringer J. R. (2003). "Seasonal cycle of carbon dioxide and its isotopic composition in an urban atmosphere: anthropogenic and biogenic effects". Journal of Geophysical Research: Atmospheres, 108, 8-1-8-8. <https://doi.org/10.1029/2003JD003865>

Pérez González, M. E., García RodríGuez, M. P. and Guerra Zaballos, A. (2003). "Análisis del clima urbano a partir de imágenes de satélite en el centro peninsular español”. Anales de Geografía de la Universidad Complutense, 23, 187-206.

Pringle, M., SCHMidT, M. AND MuIR, J. S. (2009). "Geostatistical interpolation of SLC-off Landsat ETM+ images". ISPRS Journal of Photogrammetry and Remote Sensing, 64, 654-664. <https://doi.org/10.1016/j.isprsjprs.2009.06.001>

QuATTROCHI, D. A. and RidD, M. K. (1998). "Analysis of vegetation within a semiarid urban environment using high spatial resolution airborne thermal infrared remote sensing data". Atmospheric Environment, 32, 19-33. <https://doi.org/10.1016/S1352-2310(97)00179-9>

Ripoll, M. V., Kurbán, A., Papparelli, A., Cúnsulo, M. and Roca, G. (2010). "Condiciones térmicas de un espacio verde urbano en clima árido". Avances en Energias Renovables y Medio Ambiente, 14, 11.09-11.15.

Rosenzweig, C., Solecki, W. D., Parshall, L., Chopping, M., Pope, G. and GolDBERG, R. (2005). "Characterizing the urban heat island in current and future climates in New Jersey". Environmental Hazards, 6, 51-62. $<$ https://doi.org/10.1016/j.hazards.2004.12.001> 
SANTANA, L. (2007). "Landsat ETM+ image applications to extract information for environmental planning in a Colombian city". International Journal of Remote Sensing, 28, 4225-4241. <https://doi.org/10.1080/01431160701244856>

Sarricolea, P. and Romero Aravena, H. (2006). Cambios de uso y coberturas en el suelo entre 1998 Y 2004 y sus efectos sobre la configuración de la isla de calor de urbana de superficie de Santiago. Repositorio Académico de la Universidad de Chile, Chile.

Schroeder, T. A.; Cohen, W. B., Song, C., Canty, M. J. and Yang, Z. (2006). "Radiometric correction of multitemporal Landsat data for characterization of early successional forest patterns in western Oregon". Remote Sensing of Environment, 103, 16-26. <https://doi.org/10.1016/j.rse.2006.03.008>

Sekovski, I., Newton, A. And Dennison, W. C. (2012). "Megacities in the coastal zone: Using a driver-pressure-state-impact-response framework to address complex environmental problems". Estuarine, Coastal and Shelf Science, 96, 48-56. <https://doi.org/10.1016/j.ecss.2011.07.011>

Sepulveda Moreno, O. (2006). "Problemas ambientales de Santiago: Isla de calor y edificios de vidrios". Boletín de Geografía, 24, 45-55.

Song, C., Woodcock, C., Seto, K., Pax Lenney, M. and Macomber, S. (2001). "Classification and change detection using Landsat TM data: when and how to correct atmospheric effects?”. Remote Sensing of Environment, 75, 230-244.

USGS (United States Geological Survey). <http://glovis.usgs.gov/> [Retrieved 15 ${ }^{\text {th }}$ October 2015].

VAlOR, E. and CASElles, V. (1996). "Mapping land surface emissivity from NDVI: Application to European, Africa and South American areas". Remote Sensing of Environment, 57, 167-184. <https://doi.org/10.1016/0034-4257(96)00039-9>

Valor, E., Caselles, V., Coll, C., Sánchez, F., Rubio, E. and Sospedra, F. (2000). "Análisis comparativo del efecto de la isla térmica de la ciudad de Valencia con imágenes TM, MUST y AVHRR”. Revista de Teledetección, 14, 1-6.

Velasco, E. and Roth, M. (2010). "Cities as net sources of $\mathrm{CO}_{2}$ : Review of atmospheric $\mathrm{CO}_{2}$ exchange in urban environments measured by Eddy Covariance Technique". Geography Compass, 4 (9), 1238-1259. <https://doi.org/10.1111/j.1749-8198.2010.00384.x>

VERA, P. (2013). "Imaginarios urbanos y procesos de urbanización en las nuevas ciudades turísticas. El caso de la ciudad de Rosario, Argentina". Revista Bitácora Urbano Territorial, 22 (1), 153-162.

Vilani M. and SANCHEZ, L. (2013). "Análise de Fourier e Wavelets aplicada à temperatura do ar em diferentes tipologias de ocupação". Revista Brasileira de Engenharia Agricola e Ambiental, 17 (12), 1340-1346.

WONG, N. H. and YU, C. (2005). "Study of green areas and urban heat island in a tropical city". Habitat International, 29, 547-558. <https://doi.org/10.1016/j.habitatint.2004.04.008>

YUAN, F. and BAUER, M. (2007). "Comparison of impervious surface area and normalized difference vegetation index as indicators of surface urban heat island effects in Landsat imagery". Remote Sensing of Environment, 106, 375-386. <https://doi.org/10.1016/j.rse.2006.09.003> 